It seems that if these observations are correct, we must review or re-orientate our theories on the relationship between protein deficiency in diet and the incidence of infective hepatitis. Perhaps in wartime France other protecting factors outweighed the protein deficiency. The enormous reduction in wine drinking may possibly have had some bearing.

In the past I have referred to differences in geographical distribution of cases of hepatitis ${ }^{\mathbf{1 4}}$. The results of this present survey suggest that a profitable line of research in the near future would be the investigation of the geographical distribution and route of spread of the present epidemic of infective hepatitis in Europe and Africa.

In conclusion, I wish to record my appreciation of the help accorded me by Médecin Général Sicé and Commander Guillermin, by Prof. Gougerot and all members of the staff of the Hôpital St. Louis, Paris, by Dr. Degos, secretary of the Société Française de Dermatologie et de Syphiligraphi3, by Profs. Loeper, Fiessenger and Chabrol of the Faculty of Modicine of Paris, and their assistants, by Dr. A. Vernes, and by all the other members of the French medical profession whom I encountered.

${ }^{1}$ MacCallum, Lancet, 1, 342 (1945).

${ }^{2}$ Beattie and Marshall, Brit. Med. J., i, 547 (1944).

${ }^{3}$ Marshall, Proc. Roy. Soc. Med., 37, 453 (1944).

4 Beattle and Marshall, Brit. Med. J., ii, 651 (1944).

Salamsn, King, Williams and Nicol, Lancet, ii, 7 (1944).

- Cazal, Rer. Med.-Chir. des Mal. du Foie, 16, 204 (1943).

' Chabrol, Acad. de Med., 492 (Oct. 5, 1943).

- Fabiani, Presse Med., 96 (Feb. 27, 1943)

- Gutzeit, Klin. Wschr. (June 13, 1942).

10 Northhaas, Der deutsche Militärarat., 5, 247 (1943).

1 Ruther and.Dorow, Der deutsche Militärarzt., 3, 183 (1943)

${ }_{12}$ Meythaler, quoted in Les Annali d'Igiene, 58, 6, 281 (1943).

$1 s$ Jacobelli, Annali di Med. Nav. e Col. (May and June, 1942).

14 Yarshall, Brit. J. V. D., 19, 52 (1943).

\section{THE MOYNE REPORT ON THE WEST INDIES REGION}

$I^{\mathrm{T}}$

$\mathrm{T}$ is long since complacency in Colonial rule gave place to a more critical mood in which the responsibilities of trustership could find full expression; and, more than any previous period, the interval between the World Wars was remarkable for a series of exhaustive inquiries into the social and economic health of the Colonial Empire. The survey of British Africa, directed by Lord Hailey, was the first of these ; the second, on a similarly comprehensive scale, is the report, recently published, of the Royal Commission (chairman, Lord Moyne) on West India. It is a document notable for the exceptionally wide range of its inquiry and for the realism and courage, not to mention the humanity, of its conclusions and recommendations. Two shorter documents, concermed with special aspects of social and economic conditions within the West Indies, provide a powerful reinforcement*.

Nothing indeed is lacking from the report, except only an appropriate accompaniment of maps. The

\footnotetext{
- West India Royal Commission Report. (Cmd. 6607.) Pp. xviii + $480+16$ plates. $78.6 d$. net.

West India Royal Commission. Report on Agriculture, Fisheries, Forcstry and Veterinary Matters. By F. L. Engledow. (Cmd. 6608.) Pp. vilit +235 . 3s. 6d. net.

West India Roval Commission, 1938-39. Statement of Action taken on the Recommendations. (Cnd. 6656.) Pp. 108. 28. net.

Colonial Office. Development and Welfare in the West Indies, 1943-44. Report by Sir Frank Stockdale. (Colonial No. 189.) Pp. iv +115 . 28. net.

(London: H.M. Stationery Office, 1945.)
}

only map provided is on the inadequate scale of fifty-five miles to the inch, by which the Leeward and Windward groups-and even the larger islands -appear as little more than dots on the vast expanse of the Caribbean. For at least the larger or more important Colonies a series of orographic, climatic, and other maps on a suitable scale might well have been provided. The need for cartographical aid is all the more necessary because of the scattered distribution of the British West Indies, which comprise, in addition to Jamaica, Trinidad and some islands of the Lesser Antilles, the widely separated mainland Colonies of Honduras and Guiana.

Administrative reform, in the direction of the unification of services, would seem to be more manageable and immediately possible than the amelioration of those economic and social conditions which depend as much upon the operation of causes outside the British West Indies as upon local influences. The recommendations in this field may, therefore, be mentioned first. Federation or some other close association of the Colonies, though admittedly desirable and ultimately probable, seems likely to be limited in the first instance to the union of the Leeward and Windward groups. The report is emphatic that the representation of West Indian, as of Colonial interests generally, in the Imperial Parliament is inadequate; and recommends as the most hopeful plan the association of West Indian delegates with any Standing Committee of Parliament which may be empowered to consider Colonial affairs. None of the Caribbean Colonies has attained responsible government, the nearest approach being found in Barbados, where the representative element in both the legislature and executive is considerable.

Much of the eriticism which the Commission investigated and largely accepted was that vested interests alone were able to influence Government policy. In consequence, the unofficial representatives, precluded from adequate participation in Government, have tended to adopt a consistently hostile attitude to the latter. The unfortunate effect on the continuity of policy of too-frequent changes in appointments to the higher offices also receives criticism. The rare appointment of coloured West Indians to any but the lowest grades of administration is a consequence of strong racial prejudice which is believed to be on the increase. This is the more serious in that, owing to widespread miscegenation over a long period, the ratio of white to coloured inhabitants is now very low.

The main body of the report and accompanying recommendations is inevitably devoted to the acute social and economic questions which have emerged, largely in response to the prevailing systems of land utilization and tenure. As a whole the picture is sombre and even depressing. It is frankly acknow. ledged that the economic condition of the rural as of the urban population is deplorable. Only a small and diminishing number of peasant proprietors engaged in the production of an export crop have attained anything approaching security. The foremost agricultural need is increased production of food, in order at least to maintain the existing low standard of life, and to relieve the Colonies from the present necessity of importing essential foods. Peasant agriculture is always likely to be the most helpful enterprise in the ultimate interests of the community; but progress both on small-holdings and on the smaller estates depends on far-reaching reforms of existing agricultural methods. The practice of shifting cultivation 
should be abandoned and replaced by permanent mixed farming : a similar recommendation applies to those larger proprietors who grow a single erop continuously. Agricultural departments have tended to assist the large estates, mostly company-owned, rather than the peasant holdings; and associated with this has been a tendency to neglect subsistence in favour of export crops. The normal peasant holding is too small to provide the means of an independent existence, and most peasants must supplement their incomes by employment on the estates, where the standard wage varies but little from two shillings a day.

In its reference to the urgent need for agricultural reforms the Royal Commission seems to accept too readily the view that the cultivable area of the Colonies combined cannot be greatly extended. Admitted that half the total area is in forest and that much land is too ill-drained to be at present usable, the geographical limits of agriculture are surely determined as much by the availability of capital and organisation as by the adequacy of the soil resources of the Colonies. The recommendation is urgent that immediate attention should be paid to the institution of soil surveys. For every aspect of agricultural reform the services of the Imperial College of Tropical Agriculture, Trinidad, will be necessary : indeed, it is intended that, while continuing those functions of training and research which it now undertakes for the Colonial Empire as a whole, the Imperial College should become also a research station for the Caribbean.

Only on the large estates, each approximately $8,000-10,000$ açres, are satisfactory standards of agriculture maintained; but even there a marked tendency is shown to concentrate on a single crop, which in several islands is sugar. This is hazardous on economic grounds, as well as agriculturally undesirable. Specialization of the kind is also true of the peasants, and is strongly deprecated because of the triple risk of disease, hostile climatic conditions, and low prices to which it is exposed.

All the export crops have suffered from the intense competition of larger producers in other parts of the world. It is recalled that the early settlement of the West Indies was prompted by their possible use as sources of spices and sugar, and that in time the production of sugar-cane generally predominated. For many reasons, including some operating outside the Caribbean, and including the competition of the European beet sugar industry, certain of the islands (for example, Jamaica) chose another specialized crop, though sugar remained the commorcial product of overwhelming importance in Guiana and Barbados. The latter island is easily the most closely developed of all the Colonies, and its sugar production not only greatly exceeds that of both Jamaica and Trinidad, but approximates even to that of British Guiana. It cannot be denied when assessing the causes of the eomparative prosperity of the sugar industry that the preference granted to the West Indian product by both Canada and Great Britain is of primary importance.

Only on the larger sugar estates has the yield improved steadily in recent years; and this by reason of the care taken to maintain soil fertility, and of the planting of improved varieties of cane. On those estates where agricultural standards are lower, there is too great a dependence on the possibility of growing sugar-cane continuously on the same land for many years, without loss of yield.
Bananas and cocoa, each a prominent cash-crop in parts of the West Indies, have failed to vie with sugar-cane, largely because of the diseases from which they have suffered. Nevertheless, recommendations made by the Commission are intended at least to maintain both output and markets. Unfortunately, although the West Indies are suitable for a wide range of agricultural products, no crop new to the area is known which would be likely both to grow well and to resist successfully competition from outside. It is partly the smallness of the scale on which West Indian agriculture is undertaken which explains the severity of the competition from other tropical territories. In suggesting methods for the improvement of the economy of the Colonies, the Commission is convinced of the necessity of supplementing agriculture by manufacturing industry. The prospects of inter-island trade are not regarded as high because the commodities that one Colony imports from outside the region are not usually of a type that the other West Indian Colonies produce adequately.

On the social rather than the economic plane, investigation of the condition of the population reaches conclusions of extraordinary frankness. Despite localized congestion of population-in Barbados particularly-it would seem that the concern expressed at the actual and prospective increase of population in the West Indies as a whole is not warranted by the facts. In the larger Colonies the density of population is low-lower even than seven per square mile in both British Guiana and British Honduras, which together cover much the greater part of the total area. Challenge to the claim (p. 9) that "the populations in all the British West Indian Colonies are now increasing with great rapidity" comes from the data contained in the report itself. After forty years (1896-1936) the inhabitants of British Guiana have increased by only 40,000 , while in the Leewards the position is virtually stationary $(131,000$ in $1896 ; 140,000$ in 1936), as it is also in Barbados. Indeed, there is support for the view that the economic prosperity of the larger Colonies-the mainland territories in particular-will depend to a considerable degree on immigration of suitable types; and we think of those British East Indians whose labour has long supported the relatively prosperous sugar industry of Guiana. Concerning the depressed conditions under which the coloured population exists, the terms of the report are severe. The deplorable lot of the majority of West Indians is stated to be largely determined by the absence of such protection as workers' organisations afford elsewhere. Despite chronic and widespread unemployment there has never been unemployment insurance, while public assistance is usually confined to the old and infirm, and even then only amounts to $1 s .6 d$. per week. The evidence of the plight of the greater part of the population is massive and apparently incontest. able.

The scale of the necessary reforms is obviously too vast to be met by the resources of the British West Indies alone. As in the case of any depressed area, the assistance of the community as a whole is invoked; and the community here is Britain, both metropolitan and colonial. It is especially unfortunate that the aggravation of other imperial questions which the Second World War has caused will render much more difficult than ever before that concentra. tion of attention on the West Indian problem which its gravity and complexity demand.

Walter Fitzgerald. 